\title{
"More Than a Free Bus Ride"-Exploring Young Adults' Perceptions of Free Bus Services Using a Qualitative Approach: A Case Study of Penang, Malaysia
}

\author{
Nur Sabahiah Abdul Sukor ${ }^{1, * \mathbb{D}}$, Surachai Airak ${ }^{1 \mathbb{D}}$ and Sitti Asmah Hassan ${ }^{2} \mathbb{D}$ \\ 1 School of Civil Engineering, Universiti Sains Malaysia, Nibong Tebal 14300, Penang, Malaysia; \\ surachai96@yahoo.com \\ 2 School of Civil Engineering, Faculty of Engineering, Universiti Teknologi Malaysia, \\ Skudai 81310, Johor, Malaysia; sasmah@utm.my \\ * Correspondence: cesabahiah@usm.my
}

Citation: Sukor, N.S.A.; Airak, S.; Hassan, S.A. "More Than a Free Bus Ride"-Exploring Young Adults' Perceptions of Free Bus Services Using a Qualitative Approach: A Case Study of Penang, Malaysia. Sustainability 2021, 13, 3294.

https://doi.org/10.3390/su13063294

Academic Editor: Tomio Miwa

Received: 27 January 2021

Accepted: 12 March 2021

Published: 17 March 2021

Publisher's Note: MDPI stays neutral with regard to jurisdictional claims in published maps and institutional affiliations.

\begin{abstract}
Encouraging the younger generation to use public transport can revolutionise the way that citizens commute in the future; hence, municipalities must provide good public transport services to encourage their use. A free bus service was introduced in Penang, Malaysia, to support the sustainable agenda and to provide transport for low-income groups. However, the lack of ridership resulted in the service being far from achieving its target. This study assessed young adults' perceptions of the current free bus service in Penang to design a strategy to attract them to use the free bus. In this study, six focus group discussions (FGDs) were conducted with young adults aged between 18 and 25 years old studying in three different higher institutions located along the route of the free bus. The data collected were analysed using thematic analysis, in which four areas were identified-free service, reliability, information provision, and attractive service. Finally, this paper provides valuable input on initiatives to further encourage young adults to use the free bus service in Penang.
\end{abstract}

Keywords: free public transport; focus group discussion; sustainable transport; urban public transport; developing country

\section{Introduction}

The increasing concerns on climate change have prompted the implementation of policies aimed at reducing transport pollution. Transportation has been reported as the main contributor of carbon dioxide $\left(\mathrm{CO}_{2}\right)$ in the environment, with cars accounting for $40 \%$ of the modal share [1]. Non-Organisation for Economic Co-operation and Development (OECD) countries are expected to comprise $61 \%$ of the energy consumption in 2040, accounted for by the transportation sector due to the increase in population size and number of motor vehicles, ultimately expediting the exhaustion of resources and global warming [2]. This issue can be overcome by increasing the use of public transport, especially in the urban areas.

Urban cities worldwide have been promoting the use of public transport to reduce air pollution, energy consumption, and traffic congestion $[3,4]$. Nevertheless, the increasing ownership of private cars is becoming a major challenge to promoting the use of public transport [5-7]. Despite considerable improvements in the system, the modal share of public transport trips continues to be consistently lower than that of private cars, prompting transit agencies to consider better policies with regard to the use of public transport.

Subsidising public bus services may encourage greater use as it can reduce people's transportation expenses [8]. Free bus services should address the issues of environment, efficiency, distribution, and mobility [9]; improve public health [10], social interaction [11], and physical activities such as cycling and walking [12]; and decrease air pollution [13]. 
Some cities provide free bus services that are specific to certain social groups, e.g., London (U.K.), Canada, and China provide specific bus services for the elderly $[10,14,15]$, and London also provides particular free bus services to those aged between 12 and 18 years [16].

Free bus services are also known as fare-free public transport (FFPT) in some countries. However, there is a possibility that service providers have to bear the lost fare revenues. The FFPT policy has been observed to increase ridership in many cities [13,17]. In FrýdekMístek, Czech Republic, the FFPT was implemented in selected zones to the advantage of the residents in the city, but with certain conditions [17]. Meanwhile, residents in Tallinn, Estonia, who pay their taxes can enjoy FFPT-the policy has been successfully implemented in Tallinn to the extent that it has become the reference for other cities [18].

Nevertheless, free bus services in developing countries are different from FFPT in Europe, as buses are the backbone for low-income groups to travel. It is challenging to provide a free bus service in developing countries without government subsidies [19]. In developing countries, low-income society still needs government support for transportation expenses [11,18]. Besides low-income groups, the ridership for other groups of citizens is still low, demonstrating a need for a target promotion.

Young adults have been the focus in many studies on transport [20,21], which shows that they are the key to increasing public transport ridership. This group consists of those who are between 18 and 25 years old [22]. In developed countries, young adults studying in college or university tend to use public transport [12], but there is a lack of studies on young adults in developing countries regarding their preference towards free bus services. Following this research gap, this study explored young adults' perceptions of free bus services in order to understand the issues that restrain them from using the bus. We also expected to receive some suggestions on how to increase the bus ridership of young adults.

This research paper begins with an introduction, followed by a literature review on young adults and public bus services, the desired quality for bus services, and free bus services in developing countries. Then, the methodology is explained, and the results are presented afterwards. Next, this paper provides a discussion section that integrates the key messages and limitations of the study. Finally, we conclude the paper with recommendations for future work.

\section{Literature Review}

\subsection{Young Adults and Public Transport}

Young adults are those between the ages of 18 and 25 years [22,23]. They are at a different stage to adolescence and adulthood in terms of social roles and normative expectations [12]. Their roles in a social group and their perceptions towards others' thoughts are different to those in adolescence and adulthood. While some refer to young adults as "millennials" [24], those who are born between the early 1980s and the late 1990s are referred to as Generation Y [24,25]. In slight contrast, in transport economics and transport research, the age of young adults can differ according to the purpose of the study; it can be between 17 and 25 years old [26], between 18 and 29 years old [27], or between 18 and 34 years old [28]. Studies that involve young adults are important to gauge their perspectives based on their abstract thinking and their ability to gather information available to establish their conclusions [29].

Many studies have demonstrated that people tend to favour cars to travel compared to public transport $[30,31]$, as they provide a sense of excitement, autonomy, freedom, protection, and privacy $[30,32,33]$. Moreover, using cars can reflect status, maturity, and a sense of identity [30,34], and they are cosy [33], convenient, predictable, and easygoing [32,33]. Travelling by car also tends to be faster than using public transport [35].

Nevertheless, there is an increasing trend that demonstrates young adults' preferences in developed countries towards public transport. The emerging trend may be due to the decline of driving licences and car ownership [23,36,37], a delay in adult life stage milestones [27,38], and environmental awareness [39-41]. 
Young adults in developed countries prefer to use public transport as they are not in a rush for a full-time job, marriage, or children, with some of them preferring to enjoy their university life and part-time jobs using public transport [27]. Young adults also tend to be unemployed or underemployed due to the changes in the socioeconomic situation, which lowers their income [34,42-44] and makes them rely on public transport as a cheaper option.

Furthermore, increasing environmental awareness among young people has increased the use of public transport in developed countries. Around $25 \%$ of the respondents aged between 16 and 34 years old in Norway demonstrate their understanding of the importance of using environmentally friendly public transport [40]. Private cars are considered to be less environmentally friendly compared to public transport [39,41]. A previous study observed that there is an increase in environmental concerns among young adults in Sweden with regard to their use of public transport compared to cars [44]. Nonetheless, young adults in developing countries express a desire for private cars, as demonstrated by young adults in Thailand, Indonesia, and the Philippines [45,46]. Their desire is mainly due to the need to fulfil a symbolic status and the failure of public transport services to meet their needs.

\subsection{Quality Desired for Bus Services}

Bus services are important to sustain the development of urban areas, as they provide mobility to different locations via a single transport facility [47] and are considered as a low-cost travel option [48]. Nevertheless, bus services tend to be dismissed due to long waiting times, uncomfortable services, safety issues, and a lack of service information, which call for an assessment on the users' desired quality from the bus services.

There have been several studies on the desired quality for bus services [48-52], demonstrating that reliability, punctuality, safety, and access to information are the top desired qualities for bus services. Reliability is one of the primary expectations of passengers [51], as it demonstrates that the service provider is committed and attentive to the outcomes [53]. Reliability is also a crucial factor for bus service preferences for efficiency and affordability, pertaining to the frequency of bus services and travel time [48].

Moreover, punctuality is also important to improve the quality of bus services $[54,55]$. Punctuality and reliability can be affected by route length, exclusive bus lanes, and distance between a stop and the origin terminal [51]. In addition, punctuality and reliability are pertinent to quality bus services, as users expect to be able to arrive and depart on time from and to their destination [56].

Additionally, safety is a paramount indicator for quality bus services and is one of the main concerns of users in selecting their mode of transportation, as some bus drivers tend to drive unsafely (over the speed limit) and disregard traffic laws, consequently repelling passengers from choosing bus services [48]. This notion was echoed in a study in Amman, Jordan, that emphasised users' safety expectations, which may also extend in terms of the approachability to transit stops [52]. Other safety components that should be considered by service providers include the risk of interference from other passengers, competent drivers, bus stop facilities, safe and recognisable bus stops, and the presence of security and police officers in designated areas [49].

Accessible travel information will also encourage more passengers to use public bus services. Information such as bus schedules and routes should be provided to the public to increase their use of public transport [48]. The availability of information will provide a sense of transport that will encourage people to use the service [52]. In providing information to bus users, customer services play a crucial role in its delivery. A study in Mauritius supports this, as the way in which crews and drivers deliver their services and the management factors such as frequency, information services, bus stops, and ticket purchasing are vital to increasing the number of public bus users [50]. 


\subsection{Free Bus Services}

The urban population in developing countries is expected to increase to 4 billion in 2030 [57], thus creating challenges in rapid motorisation and causing traffic congestion in the future. A previous study suggested that cities in developing countries should turn to depending on bus services as the backbone of mobility due to their significance in terms of economic and social costs [48]. Bus services must be at the forefront of urban mobility strategy to mitigate the effects of rapid motorisation and traffic congestion. This is because, in the developing world, bus services are also focused on providing affordable transport services to the urban poor. In the future, bus services must become a mode of choice even for those who can afford a private vehicle. Thus, providing a free bus service is one way to encourage its usage in developing countries.

Approximately 100 cities around the world offer free public transport, with most of them in Europe [58]. Despite the apparent simplicity of FFPT, its implementation can vary-some cities offer a comprehensive FFPT programme, while some only implement the approach in a specific part of urban society or space [59]. The world's first capital city to offer free public transport to its residents was Tallinn, Estonia, in 2013. Recently, bus fares were waived in 11 of its 15 counties, in line with Estonia's aim to become the first country with free nationwide public transport in 2018. The idea of free transport in Tallinn was prompted by the 2008 financial crisis, and the free bus services were punctual and well-maintained with enough seats for its users and no ticket needed [60].

Meanwhile, Luxembourg recently became the first country with a nationwide free public transport system based on a national policy to combat traffic congestion. As of 1 March 2020, those in Luxembourg are able to ride public trams, buses, and trains for free. Aside from the obvious improvement in traffic congestion, free public transport has positively impacted the country's tourism industry, as residents and visitors can both use the free public system, removing tourists' worry of having to buy public transport passes [61,62].

In Malaysia's case, the state government of Penang introduced a free bus servicecentral area transit (CAT) - in 2009 with only 23 routes. The shuttle service was an initiative to attract tourists by the Penang Island Municipal Council with a return route from Weld Quay to Penang Road between 6:00 a.m. to 12:00 a.m. [63]. In 2018, an additional 12 routes were introduced to facilitate low-income groups and to encourage shifting the transport mode from private vehicles to buses. Moreover, the CAT was introduced to improve residents' quality of life and work, allowing Penangites to reduce their transportation costs. In addition, the aim of the free bus service in Penang was to reduce air and noise pollution, consumption of fuel, and traffic congestion, in line with the Penang Green Agenda [64]. The route covers essential routes such as the hospitals, schools, government offices, shopping complexes, and markets, increasing the accessibility of these places, especially for those in low-income groups. Despite the advantages, the ridership for the free bus service is still far from on target. Therefore, it is important to understand the attitudes of passengers and their expectations, needs, and perceptions of current bus services to ensure that said services are fully utilised by the public $[65,66]$.

\section{Study Area}

Penang is a state in peninsular Malaysia that is divided into an island and the mainland, and is the only state that provides a free bus service to its residents and non-residents. Penang is reported as having the second-highest car ownership ratio after Kuala Lumpur, where every resident owns a car-there are $877 \mathrm{cars} / \mathrm{km}^{2}$ in Penang [67]. With such a high ratio, the state has a serious traffic congestion issue. The population on Penang Island is expected to grow to 989,400 by 2030 , which will increase the economic activity, traffic volume, and transport demand. If the traffic issues are not addressed, the overall number of vehicle kilometres travelled on Penang roads will increase by over $70 \%$, the traffic condition will worsen, and the use of public transport will remain low. In 2013, the 
ratio of dependency on public transport to private vehicles in Penang was approximately 10:90 [68], which is believed to be similar to the current situation.

The specific location of the study area is Nibong Tebal town, located on Penang mainland. The population of the study area is 40,072 for $0.6734 \mathrm{~km}^{2}$. Nibong Tebal has two types of bus services operated by the same operating company. The first is the regular buses that must be paid on the basis of the determined rate of fare, and the second is the free bus service subsidised by the state government. The regular buses take passengers from Nibong Tebal to other locations in Penang, while the free buses are designed for travel purposes in Nibong Tebal only.

The free bus service in Nibong Tebal was launched in 2018 and has a frequency of 20 min, with operations from 6:00 a.m. to 8:00 p.m. Figure 1 shows the location of Nibong Tebal town and the free bus service route that surrounds residential areas, schools, and higher learning institutions. The state government provides the free bus service in Nibong Tebal to facilitate the mobility of low-income groups and students in this area in order to support the objectives of the Penang Green Agenda. However, the ridership is still not achieving its target. Figure 2 shows the ridership statistics for the free bus service in Nibong Tebal from April 2018 to January 2019.

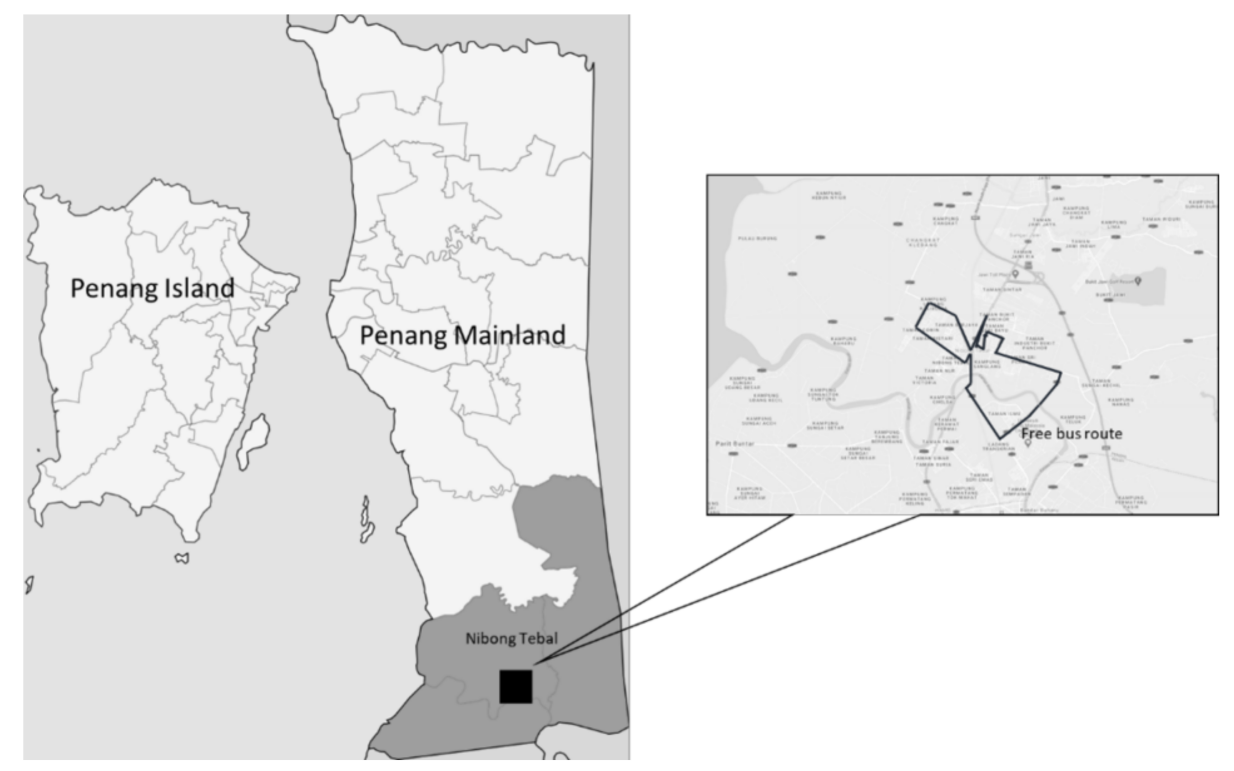

Figure 1. Free bus route in Nibong Tebal, Penang, Malaysia.

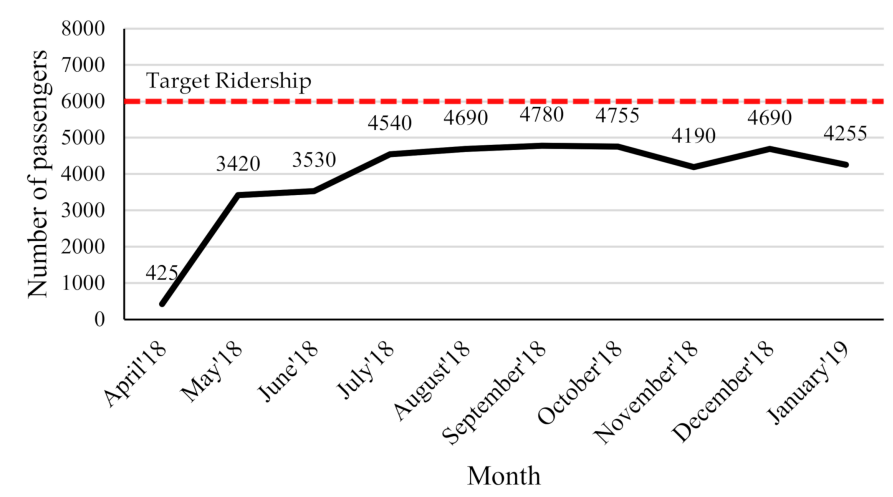

Figure 2. Ridership of free buses in Nibong Tebal from April 2018 to January 2019.

\section{Methodology}

This study employed the qualitative approach to gain an in-depth understanding of young adults' perceptions towards the free bus service. The qualitative approach was 
chosen as it allows people to express their thoughts without the restriction of a set of answers or a scale that is typical in questionnaires or other quantitative methods.

\subsection{Focus Group Discussion (FGD)}

The goal of a focus group discussion (FGD) is to obtain an in-depth understanding from a selected group of people from a similar background, instead of a representative sample of a larger population [69,70]. Moreover, it allows for the discovery of data or ideas that may be missed in individual interviews [71]. Nonetheless, focus groups restrict the number of participants to stem the interaction effect among respondents. Therefore, this study does not represent the entire population of young adults in Penang, and instead focuses on the students that wanted to share their thoughts on the free bus service. The data were gathered through the discussions of six focus groups in November 2019, and the objective was to inquire about the participants' perceptions towards free bus services.

\subsection{Participants}

The respondents were students from three different higher institutions located nearby the free bus route in Nibong Tebal. The recruitment was done on a voluntarily basis. The announcement stated that the volunteers must be current or potential users of the CAT free bus service. "Current users" were those who used the bus service regularly as their mode of transportation, while "potential users' were those who used the service occasionally or intended to use the service in the future. "Regular" in this context refers to using the bus service every week, either on weekdays or at weekends; meanwhile, "occasionally" refers to using the bus service less than twice per month or never using the bus service. Permission from the management of the higher institutions to establish FGDs was acquired, and the management later assisted in the recruitment of volunteers between 18 and 25 years old. The focus groups comprised voluntary participants from the following higher institutions: Vocational College (Group $1=10$ participants, Group $2=10$ participants), Technical Training Institute (Group $3=9$ participants, Group $4=$ 7 participants), and Universiti Sains Malaysia (Group $5=6$ participants, Group $6=6$ participants). The characteristics of the respondents based on the institution are presented in Table 1. For the Vocational College, the average age of the respondents was 19, with female students dominating $60 \%$ of the group, and $70 \%$ of the respondents were current users, while the rest were potential users. The average age of the respondents for the Technical Training Institute was 20 years old, with $56 \%$ being female and $44 \%$ being male, and $63 \%$ being current users and $37 \%$ being potential users. For Universiti Sains Malaysia, the average age of the respondents was 23 years old, with $67 \%$ being female and $33 \%$ being male, and $67 \%$ being current users and $33 \%$ being potential users. The higher institutions in this study provide rental accommodation to their students on their campuses; thus, all participants in this study were staying on campus.

\subsection{Procedure for Data Collection}

There were two researchers in each focus group that acted as a moderator and a note-taker. The moderator led the discussion and provided ample time for the participants to discuss and respond to the topic while being recorded using a voice-recorder application. The participants were first briefed on the goals and objectives of the study and the procedure of the focus group. They were also informed that they would be recorded and that their discussion would be transcribed later, but their anonymity was guaranteed. The participants were also required to sign a consent form. The duration of each session was not more than $1 \mathrm{~h}$.

After the initial briefing, the topic discussion began based on the discussion guide presented in Table 2, which is consistent with the recommended focus group methodology [72]. The guidance was necessary to establish relevant questions with proper wording and arrangement, in addition to ensuring that it answers the main topic of this study. Moreover, the guidelines provided a focused structure that consisted of opening questions, 
introductory questions, transition questions, key questions, and ending questions. Each participant was given a token of appreciation at the end of the session.

Table 1. Descriptive statistics of the respondents of the focus group discussions (FGDs).

\begin{tabular}{|c|c|c|c|c|c|}
\hline \multirow[b]{2}{*}{ Institution } & \multicolumn{2}{|c|}{ Gender } & \multirow{2}{*}{$\begin{array}{c}\text { Age } \\
\begin{array}{c}\text { Mean (Standard } \\
\text { Deviation) }\end{array}\end{array}$} & \multirow[b]{2}{*}{ Current User $n(\%)$} & \multirow{2}{*}{$\begin{array}{l}\text { Potential User } n \\
(\%)\end{array}$} \\
\hline & Female $n(\%)$ & Male $n(\%)$ & & & \\
\hline $\begin{array}{l}\text { Vocational College } \\
\text { Group } 1 \text { (10 participants) } \\
\text { Group } 2 \text { (10 participants) } \\
\text { Total participants }=20\end{array}$ & $12(60)$ & $8(40)$ & $19(0.79)$ & $14(70)$ & $6(30)$ \\
\hline $\begin{array}{c}\text { Technical Training } \\
\text { Institute } \\
\text { Group } 3 \text { ( } 9 \text { participants) } \\
\text { Group } 4 \text { (7 participants) } \\
\text { Total participants = } 16\end{array}$ & $9(56)$ & $7(44)$ & $20(1.26)$ & $10(63)$ & $6(37)$ \\
\hline $\begin{array}{l}\text { Universiti Sains Malaysia } \\
\text { Group } 5 \text { (6 participants) } \\
\text { Group } 6 \text { (6 participants) } \\
\text { Total participants }=12\end{array}$ & $8(67)$ & $4(33)$ & $23(0.55)$ & $8(67)$ & $4(33)$ \\
\hline
\end{tabular}

Table 2. FGD guidelines.

\begin{tabular}{|c|c|c|}
\hline Question Type & Purpose & Question \\
\hline Opening & $\begin{array}{l}\text { To establish rapport between the } \\
\text { participants and the researchers }\end{array}$ & $\begin{array}{l}\text { Tell us your name and your higher } \\
\text { institution. }\end{array}$ \\
\hline Introduction & To begin the topic discussion & $\begin{array}{l}\text { Have you seen the central area transit } \\
\text { (CAT) bus in this area? What do you } \\
\text { know about the CAT service provided by } \\
\text { Rapid Penang? }\end{array}$ \\
\hline Transition & To move towards the key questions & $\begin{array}{l}\text { What is your opinion on the CAT free bus } \\
\text { service in Penang? }\end{array}$ \\
\hline Key & $\begin{array}{l}\text { To obtain general perceptions towards } \\
\text { the CAT bus service }\end{array}$ & $\begin{array}{l}\text { Have you tried to use this service? Why } \\
\text { do you not use the CAT bus service? } \\
\text { (asked to potential bus users) What is } \\
\text { your general perception of the CAT bus } \\
\text { service in Penang? } \\
\text { In your opinion, what are the benefits or } \\
\text { drawbacks of the service? }\end{array}$ \\
\hline Transition & & $\begin{array}{l}\text { In your opinion, who would be likely to } \\
\text { use and not use the CAT bus service in } \\
\text { Penang? }\end{array}$ \\
\hline Key & $\begin{array}{l}\text { To investigate the cause of low bus } \\
\text { ridership from the participants' } \\
\text { perspective }\end{array}$ & $\begin{array}{l}\text { In your opinion, why is the ridership of } \\
\text { the CAT bus service low? }\end{array}$ \\
\hline Transition & & $\begin{array}{l}\text { Do you think young people like to use } \\
\text { the CAT bus service? }\end{array}$ \\
\hline Key & $\begin{array}{l}\text { To determine the factors that may } \\
\text { increase the intention to use the CAT bus } \\
\text { service among young people }\end{array}$ & $\begin{array}{l}\text { What is your suggestion to attract young } \\
\text { people to use the CAT bus service? }\end{array}$ \\
\hline Ending & To close the discussion & $\begin{array}{l}\text { Is there anything that you want to add as } \\
\text { a conclusion for your suggestions? }\end{array}$ \\
\hline
\end{tabular}




\subsection{Data Analysis}

The audio of the FGDs was transcribed into a specific form and was compared to the interviewers' notes to fill in any missing words or sentences. The transcript was also translated into English for linguistic validity. Next, the raw information in the transcript was categorised according to the context of the research questions using thematic analysis. Thematic analysis is an approach to identify, organise, and offer insights into patterns of themes across several items of qualitative data [73]. It provides the mechanics of systematically coding and analysing data and linking data to broader theoretical concepts. To analyse the raw transcript, specific words were labelled with specific codes, followed by the extraction of the words and sentences that were useful for the analysis. The words were also categorised according to themes and objectives. Lastly, the categories were established for writing purposes. The quantitative count method [12] was also used in this study-in the results, we used "all" if $100 \%$ of the participants discussed the issue, "almost all" for $75 \%$ and over, "some" for between $50 \%$ and $75 \%$, "few" for between $25 \%$ and $50 \%$, and "nobody" if there was no involvement.

\section{Results}

The main findings of this study are presented in this section. Based on the FGDs, the results were categorised into: (i) the general perceptions of the free bus service, (ii) the factors affecting bus ridership, and (iii) the suggestions to increase ridership for the free bus service.

\subsection{The General Perceptions of the Free Bus Service}

All participants perceived that the free bus service was good. Nonetheless, there were also some negative perceptions of the service. The findings of this sub-topic are presented according to positive and negative perceptions. Figures 3 and 4 show the number of responses that arose during the FGDs based on specific themes. For positive perceptions, three main themes were identified: free service, safety, and reduced congestion. Meanwhile, for negative perceptions, five themes were identified: time management, weather, lack of information, being unable to carry heavy goods, and stranger danger. The main conversation recorded during the FGDs is reported in a sub-topic below.

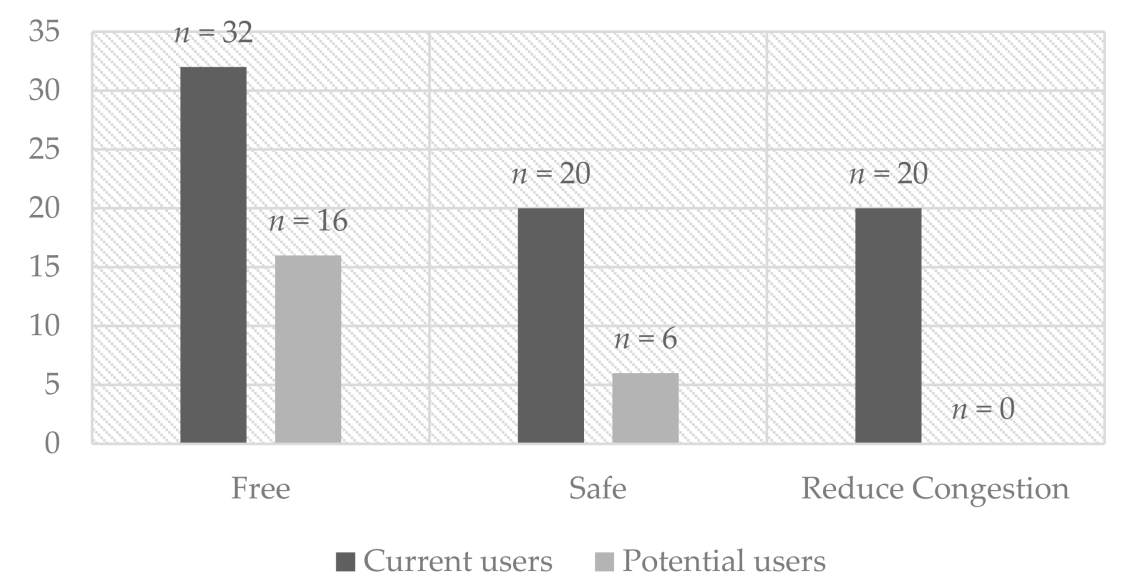

Figure 3. Number of responses highlighting specific themes in the positive perceptions towards the bus service. 


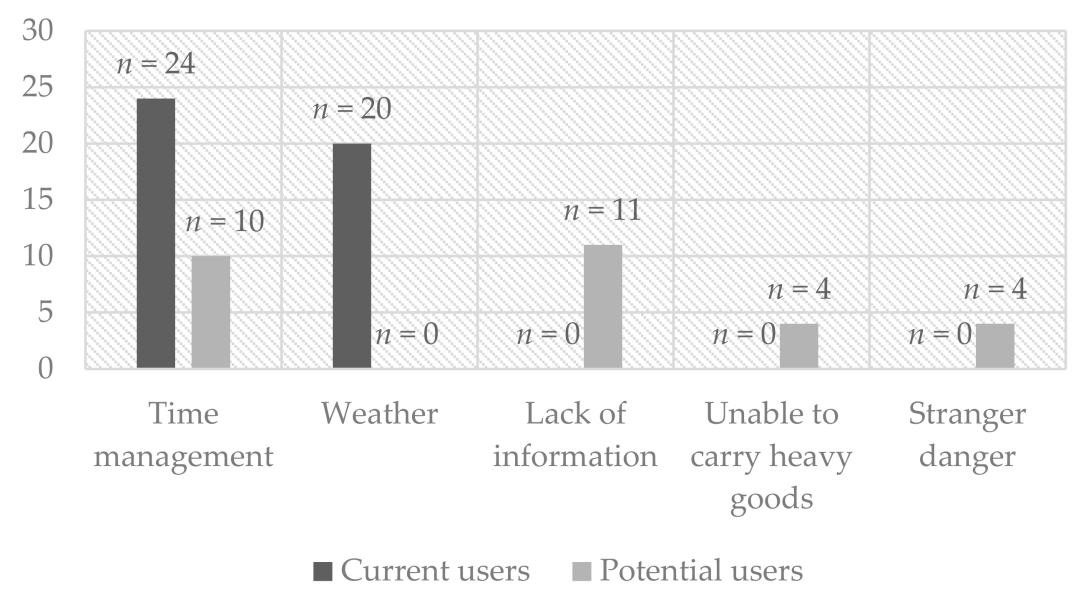

Figure 4. Number of responses highlighting specific themes on the negative perceptions towards the bus service.

\subsubsection{Positive Perceptions}

The free service was reported to have caught the attention of all respondents.

"From my experience, the CAT service is good and saves my money because it is free. As students, we always like free things" (Male, Current User, Group 1).

"Sometimes I want to go somewhere to just release my stress. So, I can use the bus anytime, since it is free" (Female, Current User, Group 3).

In addition to the students, the free bus service was stated to also benefit lowincome citizens.

"Overall, the service is good and saves money. I can see many low-income people using the service" (Male, Current User, Group 6).

"From my observations, the bus runs very well, I can see school students using it. It must be a good service- the free bus lessens parents' burden to pay school transportation costs" (Female, Potential User, Group 5).

Almost all potential users planned to try the service in the future.

"I want to try it in the future because I believe it is a good service. I do not have to spend my money to travel if I use the service. But I do not have this opportunity at the current time" (Female, Potential User, Group 4).

The participants also claimed that the bus service was superior in safety compared to other modes of transportation. Some current users stated that it was better than riding motorcycles, as most young people tended to use motorcycles to travel to schools or colleges.

"I choose to use the bus because I feel safe compared to riding a motorcycle. The driver drives safely and follows the traffic rules. I can see many students riding a motorcycle and speeding in a rush to college" (Female, Current User, Group 3).

There were also similar perceptions from a few potential users.

"I've never tried the service, but I perceive it to be good and safe for students because I can see that some of my friends use it. Most of them use it to get back home from college" (Male, Potential User, Group 1).

"I also think the bus service is safer than riding a motorcycle. I can see some old people using it. I do not use it because I do not have company to ride together with. If my friend were to ride it, I would ride it too" (Female, Potential User, Group 3).

The driver's attitude also affected the general perceptions. 
"I think the bus service is good and safe. The buses seem to follow the traffic rules and are less likely to speed" (Male, Potential User, Group 4).

A few current participants agreed that the free bus service reduces traffic congestion.

"The purpose of the bus service is somehow to avoid congestion. It is a good service, being promoted by the state government ... especially when it is free for citizens" (Male, Current User, Group 2).

"I think it is a good service from the state government to combat pollution and congestion issues" (Female, Current User, Group 6).

The positive perceptions towards the bus service and the number of responses found in the conversations during the FGDs are summarised in Figure 3 below.

\subsubsection{Negative Perceptions}

Almost all current users stated that the quality of the time management yielded a negative impression of the bus service.

"Even though the free service is good, the waiting time for the bus is sometimes too long. We do not know the actual arrival time. It creates a problem, since we also have other plans to do" (Male, Current User, Group 5).

"I only have a problem with the waiting time. That is all" (Male, Current User, Group 6).

Some of the potential respondents believed that the schedule should be improved.

"Hmm...how to use the bus if the time is not suitable, especially on Friday. We have to wait a long time, especially during Friday afternoon, and it makes us shift to other modes" (Female, Potential User, Group 2).

"The bus is not punctual at all" (Male, Potential User, Group 5).

Meanwhile, some of the current users demonstrated a sense of uncomfortableness with the condition of the buses.

"I do not know about others, but the air conditioning is not comfortable for me. Sometimes it's hot in the bus, especially in hot weather. They must do something with the air conditioning" (Male, Current User, Group 5).

Moreover, some of the potential users perceived that it was difficult to use the bus service due to a lack of information available. Many of them were eager to try the service as they believed that the service was good, but they did not have enough information about the service.

"The information about routes is confusing. I am not sure of the destination for the buses" (Female, Potential User, Group 1).

"How can we know that the coming bus is going to the place that we want to go? There is no information at the bus stops" (Female, Potential User, Group 2).

A few of the potential users stated that using the bus restricted their ability to carry many things.

"It is hard to use the bus if we go shopping, right? We need to carry many things, so it is not so comfortable. That is why I always use cars" (Female, Potential User, Group, 3).

A few of them also expressed their concerns with regard to safety issues.

"I stay in the nearby residential area. I think the access to the bus stops is too quiet and quite far. Actually...I do not feel safe walking alone" (Female, Current User, Group 1).

"Even though it is free, I do not think it is safe for small children or primary school students. There are many cases of stranger danger nowadays" (Female, Potential User, Group 6). 
The negative perception towards the bus service and the number of respondents that highlighted the issues are summarised in Figure 4 below.

\subsection{Factors Affecting Ridership}

This subsection assesses the participants' perceptions of the reason for the low ridership of the free bus service. From the qualitative data analysis, the main reasons for low ridership were bus punctuality, routes, and information. Figure 5 shows the number of responses for specific themes of the factors affecting ridership. The important content from the conversation is presented in the sub-topics below.

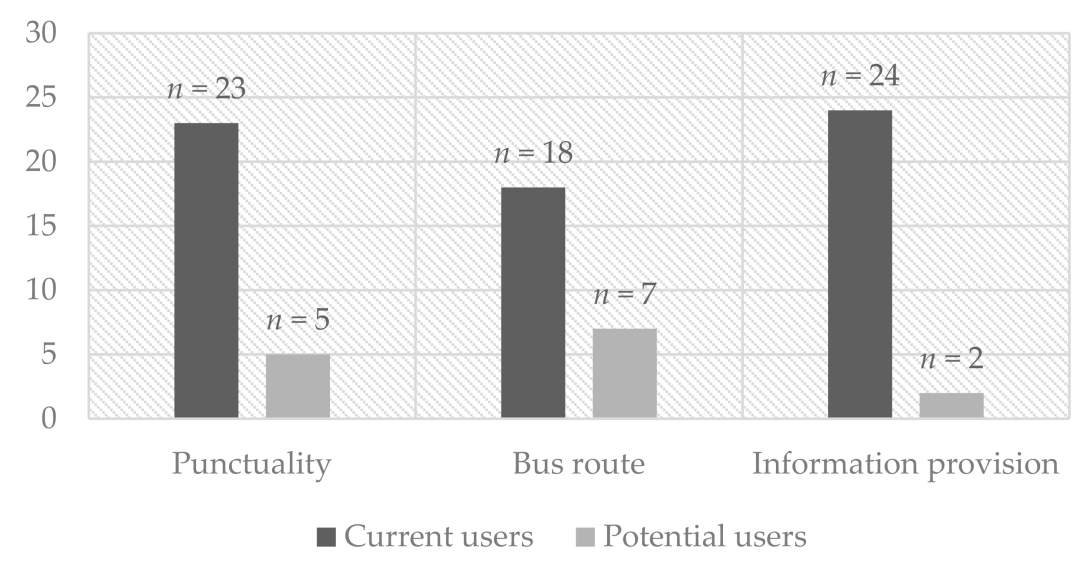

Figure 5. Number of responses highlighting specific themes for the factors affecting bus ridership.

\subsubsection{Punctuality}

Some current users agreed that the bus service punctuality and service had a significant influence on ridership, as passengers do not like to wait for a long time.

"People do not want to use the bus because it is not punctual. In addition, the bus passengers will face difficulty with time management if they use the bus. It is maybe okay for students because they do not have to rush in the afternoon...but not for working people" (Male, Current User, Group 1).

"The bus should be punctual. It must follow the timetable. So, the passengers can know at what time they should wait at bus stops. From my experience, the bus always departs late from the hub because they are waiting for passengers" (Female, Current User, Group 1).

They also shared that sometimes the buses left the bus stops earlier than scheduled.

"One day right after I finished class, I can see the bus pass by in front of the college. It was 5 min earlier than the schedule and I had to wait another 20 min for the next bus" (Male, Current User, Group 4).

A few potential users had their own perceptions of the issue.

"People would likely perceive that they need to wait longer while using the bus. So people tend to use their own vehicles, instead of the bus" (Female, Potential User, Group 5).

"It is hard to wait for a long time at the bus stops in hot weather" (Female, Potential User, Group 6).

\subsubsection{Bus Route}

A few current users suggested that the bus route causes the low ridership, as there is no connectivity between the routes. 
"The route is funny, they know that many students need to transit using other buses, but those transit bus stops are not included in the bus route, we need to go back to the hub and take a bus from there. It wastes time. Believe me, if the operator considers transit stops, many students will use it" (Male, Current User, Group 3).

"The bus route is confusing. I think it keeps changing" (Female, Current User, Group 5)

A few potential users also had issues with the bus route.

"The bus also misses the attraction places on the route such as the shopping mart and train station. The shopping mart is new, so maybe they missed during planning. But excluding the train station from the list is something that should not happen. If the bus reroutes to the train station, maybe many people will use it" (Female, Potential User, Group 4).

"The bus follows a long route before arriving at the attraction places. It will be faster if using a motorcycle" (Male, Potential User, Group 6).

\subsubsection{Information Provision}

Access to the bus route and schedule, in addition to other important information, can increase public transport ridership. Almost all current users stated that more information on the bus route, schedule, and bus stop locations was needed to attract more passengers.

"People need information to ride on a bus. Most people do not know where to find information about the free bus. I also faced the same problem at the beginning. But because I am a public bus user, I also know about the free bus service" (Male, Current User, Group 2).

"The bus operator should provide information about the route at the bus stops, including the operation time and bus schedule. Provide clear maps about the location of bus stops and transit connections. They should also have the same info on the website" (Female, Current User, Group 4).

"For the current time, the only way to know the exact location of a bus stop is by calling the service centre. The service centre will advise you where the bus stop location is and estimate the time the bus will arrive at your bus stop. It is not convenient to call the service centre every time" (Male, Current User, Group 6).

Meanwhile, a small number of potential users provided responses towards the issue.

"I know it is free, but I do not know where it is going. I think most people also face the same situation" (Female, Potential User, Group 3).

\subsection{Suggestions to Increase Ridership}

With regard to the discussion in Section 5.2, the respondents proposed several suggestions to increase bus ridership for young people in particular, which included improving punctuality, better marketing strategies, and adding attraction value to the bus service. Figure 6 presents the number of suggestions that arose from the current and potential users based on the specific themes. 


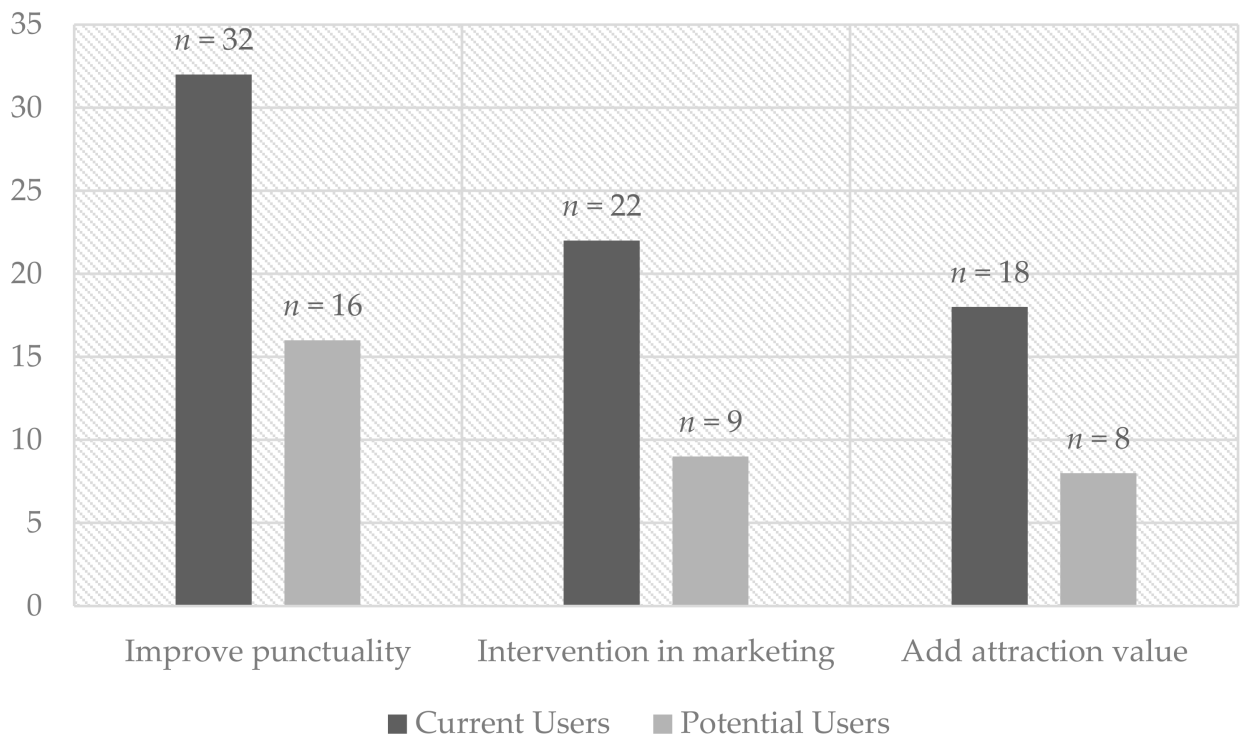

Figure 6. Number of suggestions for increasing ridership based on specific themes.

5.3.1. Improve Punctuality

All respondents stated that bus punctuality was important to increase ridership, as despite the service being free, not all passengers could wait for a long time.

"My suggestion is that the bus should be punctual. The person who faces a long waiting time on several occasions will shift to other modes of transport" (Male, Current User, Group 2).

\subsubsection{Marketing Strategy Interventions}

Some current users came up with several suggestions on marketing strategies pertaining to possible collaborations between service providers and institutions to promote the free bus service.

"How about promoting the bus service to students? Go to the institutes or schools, brief the students about the routes and attraction places, and at the same time, allow them to try the routes...for example, we can try together with friends or teachers after a school session" (Female, Current User, Group 4).

"Distribute free pamphlets in the nearby neighbourhoods. Make more social media announcements about the special or positive things about the service and attraction places. Educate through a campaign using social media" (Female, Current User, Group 5).

"Set up a campaign such as a 'use a bus day' for students involving the operators and institutions" (Male, Current User, Group 6).

Some of the potential respondents also proposed that service providers identify young people's attractions along the routes and use the places to promote the use of the bus service. For example:

"Do a market survey for the marketing strategy. Understand where young people want to go, at what time, study the possible routes that could attract them, use the attractions for those routes. For example, there are McDonalds nearby the routes where the young people like to socialise and dine together with friends." (Female, Potential User, Group 1).

\subsubsection{Add Attraction Value}

Some of the current and potential users recommended Wi-Fi networks, real-time information, and additional rewards to use the bus service.

"Include Wi-Fi on the bus. Young people will like it!" (Male, Current User, Group 1). 
"My suggestion is to provide real-time data, at the bus stops, on the website. Touch screen panels at the bus stop, at first people will be impressed with the advanced technology and this will attract them to use the service. This is because they will believe that public transport has already been improved" (Male, Current User, Group 3).

"More time riding the bus, more earned points that can be redeemed for free food, free tickets, free services, or a free data plan. Young people like that. They are usually impressed with 'cool' things" (Female, Potential User, Group 6).

\section{Discussion}

This study employed FGDs to investigate young adults' perceptions of free bus service in Penang. Our respondents in this study were students from higher institutions that agreed to volunteer in the FGDs. The results indicated three main findings: (i) the general perceptions of the free bus service, (ii) the factors affecting bus ridership, and (iii) the suggestions to increase ridership of the free bus service.

In terms of the general perceptions towards the bus service, we divided the findings into two parts, namely positive and negative perceptions. All respondents supported the free bus service because, as students, they are considered as a no-income group. Our respondents believed that the free bus service in Penang also benefits the certain social groups as well, parallel with previous studies in developed countries $[10,14,16]$. The service also allows young people to socialise with their friends at a lower cost, similar to previous studies that state that free bus services serve as a meeting place that provides social inclusion for young people $[9,74]$.

The respondents also perceived that the bus service is safer compared to other modes of transport, especially motorcycles. This is maybe due to the high intention of young people to ride motorcycles recklessly [75] and the high rate of motorcycle accidents involving young adults in Malaysia [76]. This observation indicates that the respondents had a high awareness of road safety issues in Malaysia, showing that the safe and efficient bus service may attract more young people to use the bus. Moreover, the participants noted that the use of buses is an important step to combat pollution and traffic congestion in the city, demonstrating their awareness of sustainability issues. A previous study supported this, observing that young people in Penang have high awareness and intention towards pro-environmental behaviours [77].

Nevertheless, potential users perceived the bus service as unreliable with regard to punctuality, which affects their waiting time. This unreliability is said to be the main cause of low ridership, and the participants suggested that better punctuality will attract more young riders. This finding has been corroborated in many studies $[49,52]$. This study also observed that current users are more concerned about the punctuality of the service compared to potential users, in line with previous studies [49,78].

In terms of bus routes and access to information, the participants claimed that some of the routes are impractical and the information on routes and schedules is inadequate, hindering people from using the service. This also confirms the results of previous studies $[53,54]$. Some of them suggested, to improve these factors, ensuring that the information is accessible through mobile applications and websites. Ridership could also be increased if there is real-time information on the bus service $[79,80]$. Additionally, some riders suggested free Wi-Fi on buses and at bus stops to attract young people. This is in line with a previous study [81] that observed that access to Wi-Fi can increase public transport ridership. There was also a suggestion for rewards based on the regularity of using the bus service, as earning and redeeming points are appealing to young people. A study in Brunei agreed with this, as it was observed that students from a higher level of education are likely to use buses to enjoy the rewards [82].

The participants also suggested that the service should be promoted to school and higher institution students by encouraging young people to use the service with their friends. Those who have experienced free public transport are more likely to have a positive perception towards the service, increasing their intention to use the bus [17]. 
Decorating the buses and bus stops can also increase ridership-in South Korea, bus ridership has been successfully increased by a bus makeover in Seoul, based on a television series [83]. The marketing strategy should also emphasise the safety issues of buses, which were noted as safer than motorcycles by the participants themselves.

This study has several limitations. The participants were from higher educational institutions, disallowing generalisation to school students and young working adults. Moreover, there was an imbalance between the number of current and potential users, as well as gender, due to the voluntary nature of participation. This study also did not consider vehicle ownership, alternative modes of transport, or financial condition of the respondents, which may have had an effect on the participants' perceptions towards the free bus service. In addition, some of the routes of the CAT free bus service in Penang do not have higher learning institutions and schools. Therefore, future studies should include FGDs with other groups of passengers on each route and compare the findings.

\section{Conclusions}

Free bus services in developing countries are not common, as their citizens favour private vehicles such as cars and motorcycles. However, for low-income people and students, a free bus service can become their backbone for travelling in a city. Therefore, the state government of Penang subsidised the free bus service to several localities, including Nibong Tebal. However, the number of riders is not achieving the target; thus, it is necessary to understand the fundamental problems causing the lack of ridership, or else the initiative will be wasted. This study aimed to identify the factors that affect passengers' perceptions of the public transport service. Four important aspects emerged from the analysis, focused on free, reliable, informative, and attractive bus services.

Our work found that a free bus service is not the only factor to attract ridership from young adults. Young adults demand a reliable bus service, noting the amount of time wasted waiting at a bus stop. Millennials also prefer to be connected to an online network for real-time information and tend to be frustrated if they fail to acquire exact information on the attractions along bus routes, real-time information of the bus, and the exact departure and arrival times. They are also interested in appearing "cool" and "trendy" while using transport; thus, the bus service needs to achieve the level of symbolic status. We also suggest improving the visibility of the free bus service through marketing interventions, joint-venture campaigns between the operator and academic institutions, and organising related events.

For future research, this study suggests the inclusion of school students in an in-depth interview or an FGD. This must also consider the balance between genders to explore the issues from male and female perspectives. Other factors that should be considered are vehicle ownership and alternative modes of transport to address the opinions and suggestions on how to improve the quality of the bus service from the participants that possess private vehicles. The factors above should be addressed to improve the free bus service in order to attract young people to use the bus as their main mode of transportation.

Author Contributions: Conceptualization, N.S.A.S.; methodology, N.S.A.S.; formal analysis, N.S.A.S.; writing—original draft preparation, N.S.A.S.; writing—review and editing, S.A.; visualization, S.A.; supervision, N.S.A.S.; project administration, N.S.A.S.; funding acquisition, N.S.A.S. and S.A.H. All authors have read and agreed to the published version of the manuscript.

Funding: This research was funded by Universiti Sains Malaysia (RU Grant), grant number 1001. PAWAM.8016122.

Institutional Review Board Statement: The study was conducted according to the guidelines of the Declaration of Helsinki, International Conference on Harmonization (ICH) Guidelines, Good Clinical Practice (GCP) Standards, Council for International Organizations of Medical Sciences (CIOMS) Guidelines, World Health Organization (WHO) Standards and Operational Guidance for Ethics Review of Health-Related Research and Surveying and Evaluating Ethical Review Practices, EC/IRB Standard Operating Procedures (SOPs), Local Regulations and Standards in Ethical Review and 
approved by the Human Research Ethics Committee USM (HREC) of Universiti Sains Malaysia (protocol code USM/JEPeM Code/20020078 on 17th June 2020).

Informed Consent Statement: Informed consent was obtained from all subjects involved in the study. Data Availability Statement: Not Applicable.

Conflicts of Interest: The authors declare no conflict of interest.

\section{References}

1. Shaheen, S.A.; Lipman, T.E. Reducing greenhouse emissions and fuel consumption: Sustainable approaches for surface transportation. IATSS Res. 2007, 31, 6-20. [CrossRef]

2. International Energy Agency. World Energy Outlook 2016; International Energy Agency: Paris, France, 2016.

3. Land Transport Authority. Passenger Transport Mode Shares in World Cities. Journeys, November 60-70. Available online: https:/ / www.lta.gov.sg/ltaacademy/doc/J11Novp60PassengerTransportModeShares.pdf (accessed on 8 November 2020).

4. Guerreiro, C. Air Quality in Europe: 2013 Report. Available online: https://www.eea.europa.eu/publications/air-quality-ineurope-2013 (accessed on 10 November 2020).

5. Kamargianni, M.; Matyas, M.; Li, W.; Muscat, J. Londoners' Attitudes towards Car-Ownership and Mobility-as-a-Service: Impact Assessment and Opportunities that Lie Ahead; MaaSLab-UCL Energy Institute: London, UK, 2018.

6. Oostendorp, R.; Gebhardt, L. Combining means of transport as a users' strategy to optimize traveling in an urban context: Empirical results on intermodal travel behavior from a survey in Berlin. J. Transp. Geogr. 2018, 71, 72-83. [CrossRef]

7. Li, D.; Ye, X.; Ma, J. Empirical Analysis of Factors Influencing Potential Demand of Customized Buses in Shanghai, China. J. Urban Plan. Dev. 2019, 145, 05019006. [CrossRef]

8. Guzman, L.A.; Oviedo, D. Accessibility, affordability and equity: Assessing 'pro-poor'public transport subsidies in Bogotá. Transp. Policy 2018, 68, 37-51. [CrossRef]

9. Fearnley, N. Free Fares Policies: Impact on Public Transport Mode Share and Other Transport Policy Goals. Int. J. Transp. 2013, 1, 75-90. [CrossRef]

10. Green, J.; Jones, A.; Roberts, H. More than A to B: The role of free bus travel for the mobility and wellbeing of older citizens in London. Ageing Soc. 2014, 34, 472-494. [CrossRef]

11. Tansawat, T.; Kanitpong, K.; Kishi, K.; Utainarumol, S.; Jiwattanakulpaisarn, P. The impact of public transport subsidy on social inclusion: The case of free train policy in Thailand. J. East. Asia Soc. Transp. Stud. 2015, 11, 2558-2574.

12. Simons, D.; Clarys, P.; De Bourdeaudhuij, I.; de Geus, B.; Vandelanotte, C.; Deforche, B. Why do young adults choose different transport modes? A focus group study. Transp. Policy 2014, 36, 151-159. [CrossRef]

13. Hsu, M.T.; Chiu, C.H.; Chen, H.Y.; Ho, L.H. The development of the free shuttle bus policy in Hsichu, Taiwan. Adv. Mater. Res. 2012, 482, 417-420. [CrossRef]

14. Mah, S.; Mitra, R. The effects of a free bus program on older adults travel behaviour: A case study of a Canadian suburban municipality. Case Stud. Transp. Policy 2017, 5, 460-466. [CrossRef]

15. Zhang, Y.; Yao, E.; Zhang, R.; Xu, H. Analysis of elderly people's travel behaviours during the morning peak hours in the context of the free bus programme in Beijing, China. J. Transp. Geogr. 2019, 76, 191-199. [CrossRef]

16. Jones, A.; Steinbach, R.; Roberts, H.; Goodman, A.; Green, J. Rethinking passive transport: Bus fare exemptions and young people's wellbeing. Health Place 2012, 18, 605-612. [CrossRef] [PubMed]

17. Štraub, D. The Effects of Fare-Free Public Transport: A Lesson from Frýdek-Místek (Czechia). Sustainability $2020,12,9111$. [CrossRef]

18. Cats, O.; Susilo, Y.O.; Reimal, T. The prospects of fare-free public transport: Evidence from Tallinn. Transportation 2017, 44, 1083-1104. [CrossRef]

19. Motta, R.A.; Da Silva, P.C.M.; Santos, M.P.D.S. Crisis of public transport by bus in developing countries: A case study from Brazil. Int. J. Sustain. Dev. Plan. 2013, 8, 348-361. [CrossRef]

20. Sisson, S.B.; Tudor-Locke, C. Comparison of cyclists' and motorists' utilitarian physical activity at an urban university. Prev. Med. 2008, 46, 77-79. [CrossRef]

21. Haas, K.; Wilson, N.J.; Cordier, R.; Vaz, S.; Lee, H.C. The Experiences of Young Autistic Adults in Using Metropolitan Public Transport; Cooperative Research Centre for Living with Autism: Brisbane, Australia, 2020; pp. 1-28.

22. Arnett, J.J. Emerging adulthood: A theory of development from the late teens through the twenties. Am. Psychol. 2000, 55, 469. [CrossRef]

23. Hjorthol, R. Decreasing popularity of the car? Changes in driving licence and access to a car among young adults over a 25-year period in Norway. J. Transp. Geogr. 2016, 51, 140-146. [CrossRef]

24. De Vos, J.; Alemi, F. Are young adults car-loving urbanites? Comparing young and older adults' residential location choice, travel behavior and attitudes. Transp. Res. Part A Policy Pract. 2020, 132, 986-998. [CrossRef]

25. Thigpen, C.; Handy, S. Driver's licensing delay: A retrospective case study of the impact of attitudes, parental and social influences, and intergenerational differences. Transp. Res. Part A Policy Pract. 2018, 111, 24-40. [CrossRef]

26. Delbosc, A.; Vella-Brodrick, D. The role of transport in supporting the autonomy of young adults. Transp. Res. Part F Traffic Psychol. Behav. 2015, 33, 97-105. [CrossRef] 
27. Kuhnimhof, T.; Zumkeller, D.; Chlond, B. Who Made Peak Car, and How? A Breakdown of Trends over Four Decades in Four Countries. Transp. Rev. 2013, 33, 325-342. [CrossRef]

28. Bayart, C.; Havet, N.; Bonnel, P.; Bouzouina, L. Young people and the private car: A love-hate relationship. Transp. Res. Part D: Transp. Environ. 2020, 80, 102235. [CrossRef]

29. Moore, S. Understanding and managing anti-social behaviour on public transport through value change: The considerate travel campaign. Transp. Policy 2011, 18, 53-59. [CrossRef]

30. Mann, E.; Abraham, C. The role of affect in UK commuters' travel mode choices: An interpretative phenomenological analysis. Br. J. Psychol. 2006, 97, 155-176. [CrossRef] [PubMed]

31. Páez, A.; Whalen, K. Enjoyment of commute: A comparison of different transportation modes. Transp. Res. Part A Policy Pract. 2010, 44, 537-549. [CrossRef]

32. Anable, J.; Gatersleben, B. All work and no play? The role of instrumental and affective factors in work and leisure journeys by different travel modes. Transp. Res. Part A Policy Pract. 2005, 39, 163-181. [CrossRef]

33. Beirão, G.; Sarsfield Cabral, J.A. Understanding attitudes towards public transport and private car: A qualitative study. Transp. Policy 2007, 14, 478-489. [CrossRef]

34. Gatersleben, B. Affective and Symbolic Aspects of Car Use. In Threats from Car Traffic to the Quality of Urban Life; Gärling, T., Steg, L., Eds.; Emerald Group Publishing Limited: Bingley, UK, 2007; pp. 219-233. [CrossRef]

35. Woods, R.; Masthoff, J. A comparison of car driving, public transport and cycling experiences in three European cities. Transp. Res. Part A Policy Pract. 2017, 103, 211-222. [CrossRef]

36. Delbosc, A.; Currie, G. Causes of Youth Licensing Decline: A Synthesis of Evidence. Transp. Rev. 2013, 33, 271-290. [CrossRef]

37. Melia, S.; Chatterjee, K.; Stokes, G. Is the urbanisation of young adults reducing their driving? Transp. Res. Part A Policy Pract. 2018, 118, 444-456. [CrossRef]

38. Brown, A.E.; Blumenberg, E.; Taylor, B.D.; Ralph, K.; Voulgaris, C.T. A taste for transit? Analyzing public transit use trends among youth. J. Public Transp. 2016, 19, 49-67. [CrossRef]

39. Delbosc, A.; Currie, G. Using discussion forums to explore attitudes toward cars and licensing among young Australians. Transp. Policy 2014, 31, 27-34. [CrossRef]

40. Munim, Z.H.; Noor, T. Young people's perceived service quality and environmental performance of hybrid electric bus service. Travel Behav. Soc. 2020, 20, 133-143. [CrossRef]

41. Nurul Habib, K. Modelling the choice and timing of acquiring a driver's license: Revelations from a hazard model applied to the University students in Toronto. Transp. Res. Part A Policy Pract. 2018, 118, 374-386. [CrossRef]

42. Blumenberg, E.; Ralph, K.; Smart, M.; Taylor, B.D. Who knows about kids these days? Analyzing the determinants of youth and adult mobility in the U.S. between 1990 and 2009. Transp. Res. Part A Policy Pract. 2016, 93, 39-54. [CrossRef]

43. Delbosc, A.; McDonald, N.; Stokes, G.; Lucas, K.; Circella, G.; Lee, Y. Millennials in cities: Comparing travel behaviour trends across six case study regions. Cities 2019, 90,1-14. [CrossRef]

44. Forward, S.; Aretun, A.; Engstrom, I.; Nolen, S.; Borjesson, J. Young People's Attitudes towards Acquiring a Driving License 2002-2009; Swedish National Road and Transport Research Institute: Linköping, Sweden, 2010.

45. Belgiawan, P.F.; Schmöcker, J.D.; Abou-Zeid, M.; Walker, J.; Lee, T.C.; Ettema, D.F.; Fujii, S. Car ownership motivations among undergraduate students in China, Indonesia, Japan, Lebanon, Netherlands, Taiwan, and USA. Transportation 2014, 41, 1227-1244 [CrossRef]

46. Van, H.T.; Choocharukul, K.; Fujii, S. The effect of attitudes toward cars and public transportation on behavioral intention in commuting mode choice-A comparison across six Asian countries. Transp. Res. Part A Policy Pract. 2014, 69, 36-44. [CrossRef]

47. Ibrahim, N.H.; Mohammed-Amin, R.K.; Ali, A.F. Measuring Service Quality of Bus Services in Sulaimani City. Kurd. J. Appl. Res. 2020, 5, 270-286. [CrossRef]

48. Borhan, M.; Ibrahim, A.N.H.; Syamsunur, D.; Rahmat, R. Why Public Bus is a Less Attractive Mode of Transport: A Case Study of Putrajaya, Malaysia. Period. Polytech. Transp. Eng. 2019, 47, 82-90. [CrossRef]

49. Baharum, S.; Haron, S.; Ishak, S.; Mansor, S. Sustainable Urban Bus Service Assessment and Tourists' Satisfaction. Int. J Supply Chain Manag. 2019, 8, 570-575.

50. Champahom, T.; Jomnonkwao, S.; Karoonsoontawong, A.; Hantanong, N.; Beeharry, R.; Ratanavaraha, V. Modeling user perception of bus service quality: A case study in Mauritius. Songklanakarin J. Sci. Technol. 2020, 42, 660-670.

51. Chen, X.; Yu, L.; Zhang, Y.; Guo, J. Analyzing urban bus service reliability at the stop, route, and network levels. Transp. Res. Part A Policy Pract. 2009, 43, 722-734. [CrossRef]

52. Moslem, S.; Alkharabsheh, A.; Ismael, K.; Duleba, S. An integrated decision support model for evaluating public transport quality. Appl. Sci. 2020, 10, 4158. [CrossRef]

53. Pakurár, M.; Haddad, H.; Nagy, J.; Popp, J.; Oláh, J. The Service Quality Dimensions that Affect Customer Satisfaction in the Jordanian Banking Sector. Sustainability 2019, 11, 1113. [CrossRef]

54. Suman, H.K.; Bolia, N.B.; Tiwari, G. Comparing public bus transport service attributes in Delhi and Mumbai: Policy implications for improving bus services in Delhi. Transp. Policy 2017, 56, 63-74. [CrossRef]

55. Stojic, D.; Ciric, Z.; Sedlak, O.; Marcikic Horvat, A. Students' Views on Public Transport: Satisfaction and Emission. Sustainability 2020, 12, 8470. [CrossRef] 
56. Islam, M.R.; Hadiuzzaman, M.; Banik, R.; Hasnat, M.M.; Musabbir, S.R.; Hossain, S. Bus service quality prediction and attribute ranking: A neural network approach. Public Transp. 2016, 8, 295-313. [CrossRef]

57. United Nations, Department of Economic and Social Affairs. World Population Prospects 2019: Data Booklet 2019 (ST/ESA/SER.A/424). Available online: https://population.un.org/wpp/Publications/ (accessed on 1 March 2021).

58. Barry, E. Should Public Transit Be Free? More Cities Say, Why Not? The New York Times. Available online: https://www.nytimes com/2020/01/14/us/free-public-transit.html (accessed on 15 August 2020).

59. Kębłowski, W. Free Public Transport: Scope and Definitions. In Free Public Transport And Why We Don't Pay To Ride Elevators, 2nd ed.; Black Rose Books: Montreal, QC, Canada, 2018; pp. 1-6.

60. The Economist. Free public transport in Estonia. The Economist. Available online: https://www.economist.com/europe/2019/0 5/09/free-public-transport-in-estonia (accessed on 20 September 2019).

61. Dans, E. Is Free Public Transport In Cities The Way Forward? Forbes. Available online: https://www.forbes.com/sites/ enriquedans/2019/09/15/is-free-public-transport-in-cities-the-wayforward/?sh=769c671aa00e (accessed on 24 September 2019).

62. Hermann, M. This European Country Has Made Its Public Transportation Free. Forbes. Available online: https://www.forbes. $\mathrm{com} /$ sites/micheleherrmann/2020/03/14/luxembourgh-public-transportation-free/?sh=8d3359c13825 (accessed on 24 March 2020).

63. Rohani, M.; Wijeyesekera, D.; Abd Karim, A. Bus Operation, Quality Service and The Role of Bus Provider and Driver. Procedia Eng. 2013, 53, 167-178. [CrossRef]

64. Penang Green Council. Green Buildings and Townships. Penang Green Agenda 2030. Available online: https://www.pgc.com my/2020/wp-content/uploads/2020/09/6_PGA-Sectoral-Formatted-Final-Report_GBT.pdf (accessed on 20 February 2021).

65. Sukor, N.S.A.; Basri, N.K. Adolescents as the Target Users for Sustainable Transports. In Travel Behaviour Modification (TBM) Program for Adolescents in Penang Island; Springer: Singapore, 2019; pp. 5-11.

66. Abdul Sukor, N.S.; Khairiyah Basri, N.; Tarigan, A.K. The role of incentives towards adolescents' commitment to use public transport in Malaysia. Transp. Plan. Technol. 2018, 41, 301-318. [CrossRef]

67. Chee, W.L.; Fernandez, J.L. Factors That Influence the Choice of Mode of Transport in Penang: A Preliminary Analysis. Procedia Soc. Behav. Sci. 2013, 91, 120-127. [CrossRef]

68. Zeng, J.W.S. Exploring a Transit-Ortiented Development (TOD) Framework for Penang's Urban Growth; Penang Institute Monographs; Penang Institute: Pulau Pinang, Malaysia, 2020.

69. Basnet, H.B. Focus group discussion: A tool for qualitative inquiry. Res. A Res. J. Cult. Soc. 2018, 3, 81-88. [CrossRef]

70. Stewart, D.W.; Shamdasani, P.N. Focus Groups: Theory and Practice; Sage Publications: Newbury Park, CA, USA, 1990.

71. Morgan, D.L. Focus Groups as Qualitative Research; Sage Publications: Thousand Oaks, CA, USA, 1997.

72. Morgan, D.L.; Krueger, R.A. The Focus Group Guidebook; Sage Publications: Thousand Oaks, CA, USA, 1998.

73. Braun, V.; Clarke, V. Using thematic analysis in psychology. Qual. Res. Psychol. 2006, 3, 77-101. [CrossRef]

74. Levin, L. How may public transport influence the practice of everyday life among younger and older people and how may their practices influence public transport? Soc. Sci. 2019, 8, 96. [CrossRef]

75. Tarigan, A.K.; Sukor, N.S.A. Consistent versus inconsistent behaviour of helmet use among urban motorcyclists in Malaysia. Saf. Sci. 2018, 109, 324-332. [CrossRef]

76. Isa, M.H.M.; Jawi, Z.M.; Sarani, R.; Wong, S.V. Injury severity analysis of accidents involving young motorcycle riders in Malaysia. J. East. Asia Soc. Transp. Stud. 2011, 9, 1997-2010.

77. Basri, N.K.; Abdul Sukor, N.S. An Analysis of Pro-Environmental Attributes towards Adolescents in Penang Using Extended Theory of Planned Behaviour. In Applied Mechanics and Materials; Trans Tech Publications Ltd.: Freienbach, Switzerland, 2014; Volume 802, pp. 419-424.

78. San Santoso, D.; Yajima, M.; Sakamoto, K.; Kubota, H. Opportunities and strategies for increasing bus ridership in rural Japan: A case study of Hidaka City. Transp. Policy 2012, 24, 320-329. [CrossRef]

79. Brakewood, C. Evaluating the Impacts of Real-Time Information on Subway Ridership in New York City; University Transportation Research Center: New York, NY, USA, 2018.

80. Tiedeman, K.; Circella, G. Real-Time Riders? Millennials, Smartphone Use, and Public Transportation Ridership. In Proceedings of the Transportation Research Board 97th Annual Meeting (No. 18-06527), Washington, DC, USA, 7-11 January 2018.

81. Dong, Z.; Mokhtarian, P.L.; Circella, G.; Allison, J.R. The estimation of changes in rail ridership through an onboard survey: Did free Wi-Fi make a difference to Amtrak's Capitol Corridor service? Transportation 2015, 42, 123-142. [CrossRef]

82. Voon, N.H.; Kadir, S.N.Z.H.A.; Belayan, M.A.; Poon, S.H.; Zahran, E.S.M.M. Rides for Rewards (R4R): A Mobile Application to Sustain an Incentive Scheme for Public Bus Transport. In International Conference on Computational Intelligence in Information System; Springer: Cham, Switzerland, 2016; pp. 60-71.

83. Hwang, H.; Lee, M.J. A simple makeover can increase bus ridership: The story of Tayo bus. Transp. Policy 2020, 97, 103-112. [CrossRef] 